\title{
Amino acids based on 2,4,5-triarylimidazoles: synthesis and evaluation as new chemosensors for ion recognition
}

\author{
Cátia I. C. Esteves, M. Manuela M. Raposo and Susana P. G. Costa* \\ Centro de Química, Universidade do Minho, Campus de Gualtar, 4710-057 Braga, Portugal \\ email: spc@quimica.uminho.pt
}

\begin{abstract}
N-tert-butyloxycarbonyl-4-formylphenylalanine methyl ester and appropriate heterocyclic diones were used in the synthesis of novel fluorescent unnatural amino acids, namely 2,4,5-triarylimidazolyl-alanines. These new compounds were fully characterised by the usual spectroscopic techniques, such as IR and NMR. The photophysical properties of the amino acids were evaluated by UV-Vis absorption and fluorescence spectroscopy in solvents of different character. Interaction studies with biologically and analytically important ions such as $\mathrm{F}^{-}, \mathrm{OH}^{-}, \mathrm{Cu}^{2+}$ and $\mathrm{Fe}^{3+}$, through spectrophotometric and spectrofluorimetric titrations were carried out to assess their potential as chemosensors.
\end{abstract}

Keywords: 2,4,5-triarylimidazoles; Unnatural amino acids; Chemosensors; Fluorescence. 


\section{Introduction}

2,4,5-Triaryl-imidazoles have found application in medicinal chemistry due to their properties, for example as ligands for $\mathrm{Ru}(\mathrm{II})$ and $\mathrm{Pt}(\mathrm{II})$ complexes, as probes of DNA structure or new therapeutic agents due to their capacity to bind or interact with DNA. ${ }^{1}$ Recently we reported the synthesis of several 2,4,5-tri(heteroaryl)imidazoles with interesting photophysical properties (high fluorescence quantum yields and large Stokes' shifts) which could be used in diverse optical applications (e.g. nonlinear optics, fluorimetric chemosensors, OLEDs and DNA intercalators). ${ }^{2}$

Metallic cations can be complexed through $\mathrm{N}, \mathrm{O}$ and $\mathrm{S}$ donor atoms in amino acids, at the main and side chains, and in aromatic heterocycles, whereas anion coordination, based on hydrogen bonding and electrostatic interactions, can arise from amino acid side and main chain $\mathrm{OH}$ and $\mathrm{NH}$ groups, or from $\mathrm{NH}$ groups in heterocycles. ${ }^{3,4}$ Therefore, the insertion of suitable heterocyclic systems at the side chain of natural amino acids can add extra functionality to the amino acid.

Fluorescent sensors are preferred because they are well suited to meet the need for in vivo probes, such as mapping the spatial and temporal distribution of the biological analytes, and they have other advantages including multiple modes of detection (such as fluorescence quenching, enhancing, life time), extremely high sensitivity, relatively low cost and easy

availability. ${ }^{5}$ Our current research interests include the synthesis and characterization of unnatural amino acids, ${ }^{6}$ imidazole and benz-X-azole derivatives with interesting optical properties $^{7}$ and innovative heterocyclic colorimetric/fluorimetric chemosensors for anions and cations containing (oligo)thiophene, benzoxazole and amino acid moieties. ${ }^{8}$ We now report the synthesis and photophysical characterization of novel 2,4,5-triarylimidazolylalanines and the interaction study with biologically important ions such as $\mathrm{F}^{-}, \mathrm{OH}^{-}, \mathrm{Cu}^{2+}$ and $\mathrm{Fe}^{3+}$, through spectrophotometric and spectrofluorimetric titrations.

\section{Experimental}

\subsection{General procedure for the synthesis of 2,4,5-triarylimidazolyl-alanines 3a-b}

$\mathrm{N}$-tert-butyloxycarbonyl-4-formylphenylalanine methyl ester 1 (1 equiv.) and the appropriate heterocyclic dione 2 ( 1 equiv.) were dissolved in acetic acid ( $5 \mathrm{~mL} /$ equiv), in the presence of ammonium acetate (20 equiv.) and heated at reflux for 2 hours. After cooling, the mixture was poured over crushed ice and extracted with ethyl acetate $(3 \times 5 \mathrm{~mL})$. After drying the organic layer over anhydrous $\mathrm{MgSO}_{4}$, the solvent was removed in a rotary evaporator and a solid was 
obtained. The crude solid was purified by column chromatography, using mixtures of dichloromethane and methanol of increasing polarity as eluent.

Methyl 2-amino-3-(4-(4,5-di(furan-2-yl)-1H-imidazol-2-yl)phenyl)propanoate (3a). The product was isolated as an orange solid $(0.035 \mathrm{~g}, 0.093 \mathrm{mmol}, 57 \%) . \mathrm{Mp}=209.8-210.7^{\circ} \mathrm{C}$. IR $(\operatorname{KBr} 1 \%): v=3340,3078,2928,1737,1691,1633,1596,1526,1518,1437,1389,1368$, 1322, 1291, 1256, 1220, 1166, 1109, 1086, 1059, 1029, 994, 971, 920, 854, 813, 796, 772, $684 \mathrm{~cm}^{-1} .{ }^{1} \mathrm{H}$ NMR (400 MHz, DMSO-d 6 ): $\delta=3.06-3.20(2 \mathrm{H}), 3.72(3 \mathrm{H}),, 6.11(2 \mathrm{H}), 6.53$ $(2 \mathrm{H}), 6.99(2 \mathrm{H}), 7.14(2 \mathrm{H}), 7.50(2 \mathrm{H}), 7.84(2 \mathrm{H}) \mathrm{ppm}$. UV/Vis (ethanol, nm): $\lambda_{\max }(\log \varepsilon)=$ $317(4.21)$.

Methyl 2-amino-3-(4-(4,5-di(thiophen-2-yl)-1H-imidazol-2-yl)phenyl)propanoate (3b). The product was isolated as a yellow solid $(0.038 \mathrm{~g}, 0.094 \mathrm{mmol}, 58 \%)$. Mp = 215.9-217.0 ${ }^{\circ} \mathrm{C}$. IR (KBr 1\%): $v=3431,3146,2977,1711,1655,1596,1534,1513,1446,1419,1391$, $1366,1332,1259,1195,1168,1120,1060,1020,994,959,939,912,892,871,817,735,695$, 646, $613 \mathrm{~cm}^{-1}$. ${ }^{1} \mathrm{H}$ NMR (400 MHz, DMSO-d 6 ): $\delta=2.88-3.07(2 \mathrm{H}), 3.59(3 \mathrm{H}), 4.47-4.52$ $(1 \mathrm{H}), 7.00(1 \mathrm{H}), 7.15(1 \mathrm{H}), 7.20(1 \mathrm{H}), 7.31(2 \mathrm{H}), 7.40-7.42(2 \mathrm{H}), 7.69(1 \mathrm{H}), 7.93(2 \mathrm{H}), 8.36$ $(1 \mathrm{H}), 12.80(1 \mathrm{H}) \mathrm{ppm}$. UV/Vis (ethanol, nm): $\lambda_{\max }(\log \varepsilon)=313(4.21)$.

\subsection{Spectrophotometric and spectrofluorimetric titrations of 2,4,5-triarylimidazolyl- alanines 3a-b}

Solutions of 2,4,5-triarylimidazolyl-alanines 3 (ca. $1.0 \times 10^{-5}$ to $1.0 \times 10^{-6} \mathrm{M}$ ) and of the ions under study (ca. $1.0 \times 10^{-1}$ to $1.0 \times 10^{-3} \mathrm{M}$ ) were prepared in UV-grade acetonitrile (in the form of hydrated tetrabutylammonium salt for $\mathrm{F}^{-}$and $\mathrm{OH}^{-}$and hydrated perchlorate salt for $\mathrm{Cu}^{2+}$ and $\mathrm{Fe}^{3+}$ ). Titration of the compounds with the several ions was performed by the sequential addition of equivalents of ion to the alanine solution, in a $10 \mathrm{~mm}$ path length quartz cuvette and emission spectra were measured by excitation at the wavelength of maximum absorption for each compound.

\section{Results and discussion}

\subsection{Synthesis}

Novel 2,4,5-triarylimidazolyl-alanines 3a-b were synthesised by reaction of $\mathrm{N}$-tertbutyloxycarbonyl-4-formylphenylalanine methyl ester $\mathbf{1}$ with the appropriate heterocyclic 
dione 2 , in the presence of ammonium acetate in acetic acid at reflux for 2 hours. The pure compounds were isolated in $57 \%$ (3a) and $58 \%$ (3b) yield, and were characterized by the usual spectroscopic techniques. The acidic reaction media yielded the $N$-deprotected form of the amino acids (Scheme).

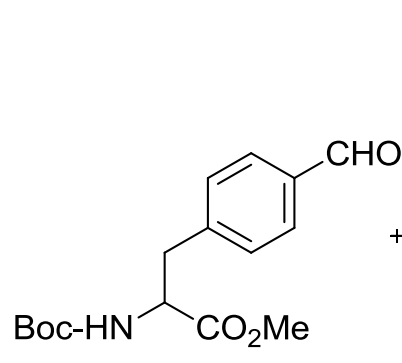

1

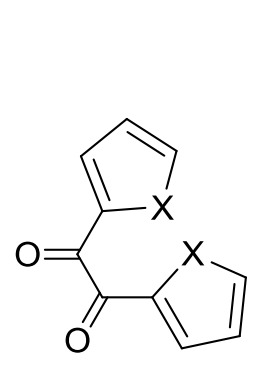

2

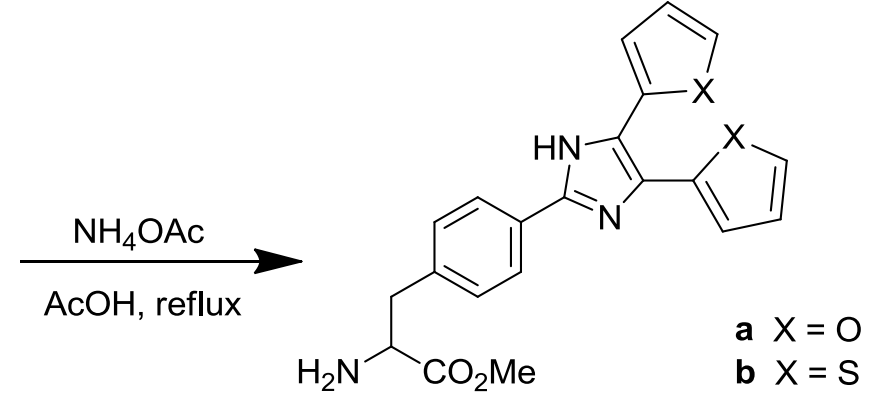

3

Scheme. Synthesis of 2,4,5-triarylimidazolyl-alanines 3a-b.

\subsection{Photophysical study of 2,4,5-triarylimidazolyl-alanines 3a-b}

The photophysical properties of compounds 3 were evaluated and the UV-vis absorption and emission spectra of degassed $10^{-6}-10^{-5} \mathrm{M}$ solutions in absolute ethanol of both compounds were measured (Table 1). Relative fluorescence quantum yields were calculated using 9,10diphenylanthracene as standard $\left(\Phi_{\mathrm{F}}=0.95\right.$ in ethanol $) .{ }^{9}$ Both 2,4,5-triarylimidazolyl-alanines 3 showed modest to high fluorescence quantum yields, and displayed large Stokes' shifts.

Table 1. UV-visible absorption and emission data for 2,4,5-triarylimidazolyl-alanines $\mathbf{3 a - b}$ in absolute ethanol.

\begin{tabular}{cccccc}
\hline & \multicolumn{2}{l}{ UV/Vis } & \multicolumn{4}{c}{ Fluorescence } \\
\cline { 2 - 6 } Compound & $\lambda_{\max }(\mathrm{nm})$ & $\log \varepsilon$ & $\lambda_{\max }(\mathrm{nm})$ & $\begin{array}{c}\text { Stokes' } \\
\text { shift }(\mathrm{nm})\end{array}$ & $\Phi_{\mathrm{F}}$ \\
\hline 3a & 317 & 4.21 & 405 & 88 & 0.72 \\
3b & 313 & 4.21 & 420 & 107 & 0.26 \\
\hline
\end{tabular}


Considering the results obtained in ethanol, the photophysical properties of 2,4,5triarylimidazolyl-alanines $\mathbf{3}$ were evaluated in other solvents of different character. The solvents tested were acetonitrile, dimethylsulphoxide, dichloromethane and diethyl ether, as examples of solvents with different polarity and proticity. The collected data revealed similar wavelengths of maximum absorption and emission and the fluorescence quantum yield did not vary significantly (Table 2).

The overall trend revealed that alanine 3a with furyl pendants was the most fluorescent (with $\Phi_{\mathrm{F}}$ in the range 0.64-0.77) whereas alanine $\mathbf{3 b}$ bearing thienyl pendants displayed the largest Stokes' shifts (between 105-109 nm).

Table 2. UV-visible absorption and emission data for 2,4,5-triarylimidazolyl-alanines 3a-b in various organic solvents of different character.

\begin{tabular}{|c|c|c|c|c|c|c|}
\hline \multirow[b]{2}{*}{ Cpd. } & \multirow[b]{2}{*}{ Solvent } & \multicolumn{2}{|l|}{ UV/Vis } & \multicolumn{3}{|c|}{ Fluorescence } \\
\hline & & $\lambda_{\max }$ & $\log \varepsilon$ & $\lambda_{\mathrm{em}}$ & $\begin{array}{c}\text { Stokes' } \\
\text { shift ( nm) }\end{array}$ & $\Phi_{\mathrm{F}}$ \\
\hline \multirow{5}{*}{$3 \mathbf{a}$} & $\mathrm{ACN}$ & 317 & 4.24 & 413 & 96 & 0.77 \\
\hline & $\mathrm{EtOH}$ & 317 & 4.21 & 405 & 88 & 0.72 \\
\hline & DMSO & 317 & 4.26 & 409 & 92 & 0.64 \\
\hline & DCM & 324 & 4.21 & 410 & 86 & 0.64 \\
\hline & Diethyl ether & 313 & 4.23 & 401 & 88 & 0.76 \\
\hline \multirow{5}{*}{$\mathbf{3 b}$} & $\mathrm{ACN}$ & 313 & 4.28 & 422 & 109 & 0.30 \\
\hline & $\mathrm{EtOH}$ & 313 & 4.21 & 420 & 107 & 0.26 \\
\hline & DMSO & 320 & 4.29 & 428 & 108 & 0.14 \\
\hline & DCM & 318 & 4.25 & 423 & 105 & 0.26 \\
\hline & Diethyl ether & 312 & 4.23 & 419 & 107 & 0.29 \\
\hline
\end{tabular}

\subsection{Spectrophotometric and spectrofluorimetric titrations of 3a-b with ions}

The modification of phenylalanine through the introduction of an extra UV-active and highly fluorescent heterocycle at its side chain was expected to provide additional binding sites for a variety of ions through the heterocycle donor atoms, as well as improved photophysical 
properties for the chemosensing studies. With heterocyclic alanines $\mathbf{3}$ it was intended to assess the influence of the structure in the chemosensing ability of anions and cations. Considering the biological, environmental and analytical relevance of ions such as $\mathrm{F}^{-}, \mathrm{OH}^{-}, \mathrm{Cu}^{2+}$ and $\mathrm{Fe}^{3+}$, the interaction of 2,4,5-triarylimidazolyl-alanines $\mathbf{3}$ with these ions was evaluated through UV-vis and fluorescence spectroscopies in spectrophotometric and spectrofluorimetric titrations in acetonitrile. In the spectrophotometric titrations, no changes were seen in the absorption spectra bands of 2,4,5-triarylimidazolyl-alanines 3a-b after addition of up to 400 equiv of each ion.

In the spectrofluorimetric titrations with $\mathrm{Cu}^{2+}$ and $\mathrm{Fe}^{3+}$, a decrease of the fluorescence intensity (a chelation-enhanced quenching, CHEQ effect) was observed for both the alanines, with an almost complete fluorescence quenching. In Figure $1 \mathrm{~A}$ is shown the spectrofluorimetric titration of alanine $3 \mathbf{a}$ with $\mathrm{Cu}^{2+}$, where the drastic effect of ion complexation is evident in the band centred at the wavelength of maximum emission at 317 nm.

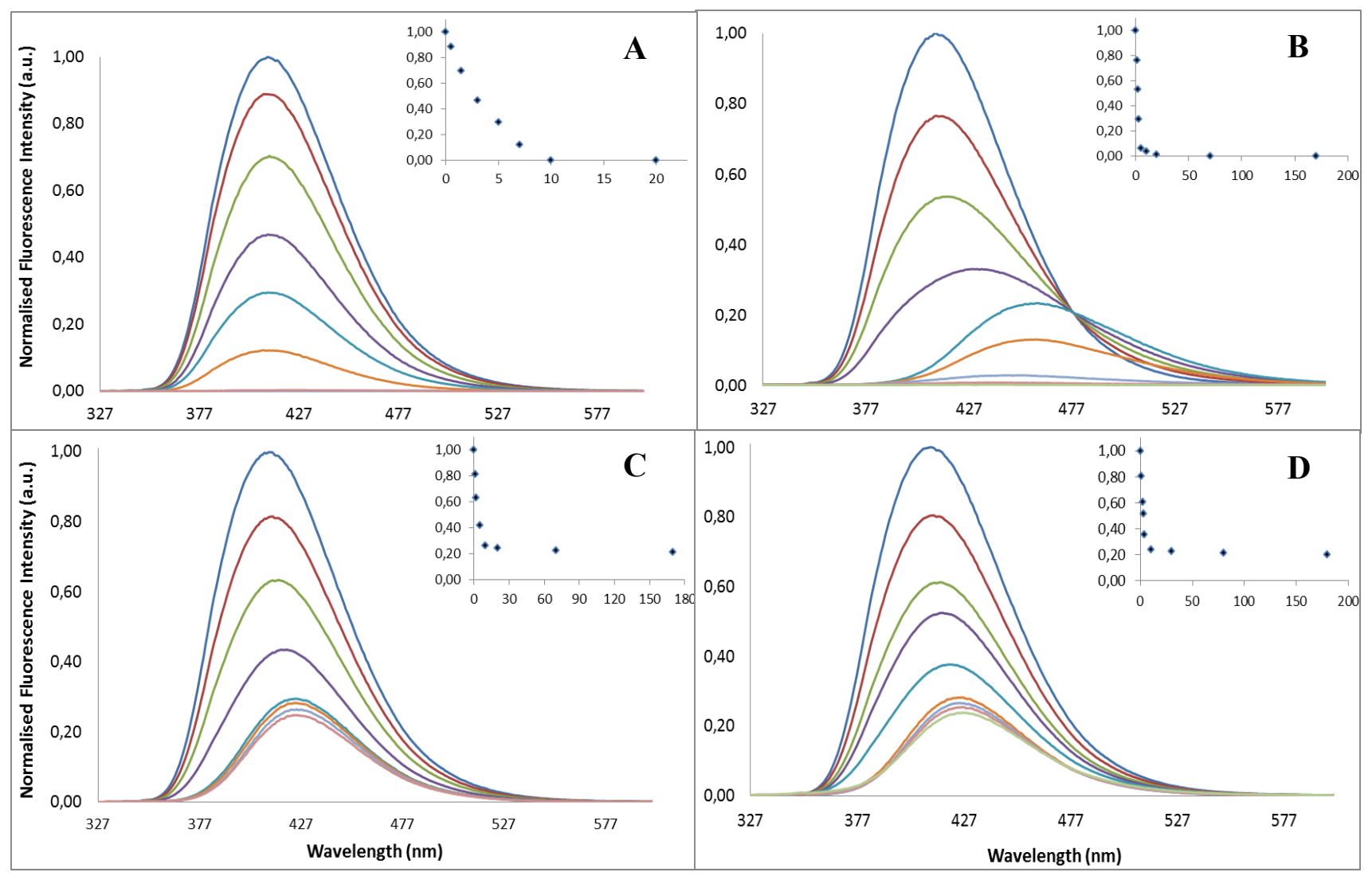

Figure 1. Fluorimetric titrations of 2,4,5-triarylimidazolyl-alanines $\mathbf{3 a}$ with $\mathrm{Cu}^{2+}(\mathrm{A}), \mathrm{Fe}^{3+}$ (B), $\mathrm{F}^{-}(\mathrm{C})$ and $\mathrm{OH}^{-}(\mathrm{D})$ in acetonitrile $\left[\lambda_{\text {exc }} 3 \mathrm{c}=317 \mathrm{~nm}\right]$. Inset: normalised emission at 413 $\mathrm{nm}$ as a function of added ion equivalents. 
With regard to the other ions $\mathrm{Fe}^{3+}, \mathrm{F}^{-}$and $\mathrm{OH}^{-}$, a less pronounced $\mathrm{CHEQ}$ effect was also observed after ion addition, without complete quenching of fluorescence, with $\mathrm{F}^{-}$and $\mathrm{OH}^{-}$. In Figure $1 \mathrm{~B}, \mathrm{C}$ and $\mathrm{D}$ are shown the spectrofluorimetric titrations of asparagine $\mathbf{3 a}$ with $\mathrm{Fe}^{3+}, \mathrm{F}^{-}$ or $\mathrm{OH}^{-}$. For $\mathrm{F}^{-}$, there was a maximum decrease of $75 \%$ and $45 \%$ in fluorescence of alanines 3a-b with the addition of 10 equiv of anion; as for $\mathrm{OH}^{-}$, a fluorescence quenching of $75 \%$ and $45 \%$ was visible with the addition of 10 equiv to alanines $\mathbf{3 a}-\mathbf{b}$; alanines $\mathbf{3 a}-\mathbf{b}$ responded highly to titration with $\mathrm{Fe}^{3+}$ with a $100 \%$ quenching after 20 and 180 equiv of metal were added.

The spectrofluorimetric titration results indicated that both 2,4,5-triarylimidazolyl-alanines were very sensitive to $\mathrm{Cu}^{2+}$, whereas the sensing of $\mathrm{Fe}^{3+}, \mathrm{F}^{-}$and $\mathrm{OH}^{-}$had lower sensitivity. Alanine 3a would be the more interesting candidate as chemosensor due to the higher fluorescence quantum yield, which is important for maximization of response to analyte in the analysis of very dilute samples.

\section{Conclusions}

The novel 2,4,5-triarylimidazolyl-alanines 3a-b are highly emissive, with modest to excellent fluorescence quantum yields ( $\Phi_{\mathrm{F}}=0.64-0.77$ for $\mathbf{3 a} ; \Phi_{\mathrm{F}}=0.14-0.30$ for $\mathbf{3 b}$ ) and display large Stokes' shifts (between 86 and $109 \mathrm{~nm}$ ) in organic solvents of different character. Alanine 3a bearing furyl pendants displayed higher fluorescence than alanine $\mathbf{3 b}$, bearing thienyl pendants, relating to the heteroatom, and larger Stokes shifts were seen for alanine $\mathbf{3 b}$, in all the solvents tested. Through spectrophotometric and spectrofluorimetric titration with several ions $\left(\mathrm{F}^{-}, \mathrm{OH}^{-}, \mathrm{Cu}^{2+}\right.$ and $\left.\mathrm{Fe}^{3+}\right)$ it was concluded that alanines 3 show a high sensitivity and ability to interact with $\mathrm{Cu}^{2+}$ and $\mathrm{Fe}^{3+}$ in $\mathrm{ACN}$.

\section{Acknowledgements}

The authors acknowledge the Fundação para a Ciência e Tecnologia (FCT, Portugal) for financial support to the NMR portuguese network (PTNMR, Bruker Avance III 400-Univ. Minho), FCT and FEDER (European Fund for Regional Development)-COMPETE-QRENEU for financial support to the research centre CQ/UM [PEst-C/QUI/UI0686/2011 (FCOMP01-0124-FEDER-022716)] and a PhD grant to C.E. (SFRH/BD/68360/2010).

\section{References}

1. Li J., Zheng W., Shi S., Tan V., Chen J., Zheng K., Ji L., J. Inorg. Biochem., 2008, 102, 193. 
2. a) Batista R. M. F., Costa S. P. G., Belsley M., Lodeiro C., Raposo M. M. M., Tetrahedron 2008, 64, 9230. b) Pina J., Seixas de Melo J., Batista R. M. F., Costa S. P. G.; Raposo M. M. M., J. Phys. Chem B, 2010, 114, 4964. c) Oliveira E., Batista R. M. F., Costa S. P. G., Raposo M. M. M., Lodeiro C., Inorg. Chem., 2010, 49, 10847. d) Pedras B., Batista R. M. F., Tormo L., Costa S. P. G., Raposo M. M. M., Orellana G., Capelo J. L., Lodeiro C., Inorg. Chim. Acta, 2012, 381, 95.

3. Shimazaki Y., Takani M., Yamauchi O., Dalton Trans. 2009, 38, 7854.

4. Santos-Figueroa L.E., Moragues M.E., Raposo M.M.M., Batista R.M.F., Ferreira R.C.M., Costa S.P.G., Sancenón F., Martínez-Máñez R., Ros-Lis J.V., Soto J., Org. Biomol. Chem. 2012, 10, 7418 .

5. Martínez-Manêz R., Sancenón F., Coord. Chem. Rev. 2006, 250, 3081.

6. a) Costa, S. P. G., Maia H. L. S., Pereira-Lima S. M. M. A., Org. Biomol. Chem. 2003, 1, 1475. b) Costa S. P. G., Oliveira E., Lodeiro C., Raposo M. M. M., Tetrahedron Lett. 2008, 49, 5258. c) Costa S. P. G., Batista R. M. F., Raposo M. M. M., Tetrahedron 2008, 64, 9733. 7. a) Batista R. M. F., Costa S. P. G., Belsley M., Raposo M. M. M., Dyes Pigments 2009, 80, 329. b) Pina J., Seixas de Melo J., Burrows H. D., Batista R. M. F., Costa S. P. G., Raposo M. M. M., J. Phys. Chem. A 2007, 111, 8574.

8. a) Costa S. P. G., Oliveira E., Lodeiro C., Raposo M. M. M., Sensors 2007, 7, 2096. b) Batista R. M. F., Oliveira E., Costa S. P. G., Lodeiro, C., Raposo M. M. M., Tetrahedron Lett. 2008, 49, 6575. d) Batista R. M. F., Oliveira E., Nuñez C., Costa S. P. G., Lodeiro C., Raposo M. M. M., J. Phys. Org. Chem. 2009, 22, 362. e) Esteves C. I. C., Silva A. M. F., Costa S. P. G., Raposo M. M. M., Tetrahedron 2009, 65, 9373. f) Esteves C. I. C., Raposo M. M. M., Costa S. P. G., Tetrahedron, 2010, 66, 7479. g) Esteves C. I. C., Raposo M. M. M., Costa S. P. G., Amino Acids, 2011, 40, 1065.

9. Morris J. V., Mahaney M. A., Huber J. R., J. Phys. Chem., 1976, 80, 969. 